\title{
A temporal common ground for learning: The moderating effect of shared mental models on the relation between team learning behaviours and performance improvement
}

Citation for published version (APA):

Santos, C. M., Uitdewilligen, S., \& Passos, A. M. (2015). A temporal common ground for learning: The moderating effect of shared mental models on the relation between team learning behaviours and performance improvement. European Journal of Work and Organizational Psychology, 24(5), 710-725. https://doi.org/10.1080/1359432x.2015.1049158

Document status and date:

Published: 01/01/2015

DOI:

10.1080/1359432x.2015.1049158

Document Version:

Publisher's PDF, also known as Version of record

\section{Document license:}

Taverne

\section{Please check the document version of this publication:}

- A submitted manuscript is the version of the article upon submission and before peer-review. There can be important differences between the submitted version and the official published version of record. People interested in the research are advised to contact the author for the final version of the publication, or visit the DOI to the publisher's website.

- The final author version and the galley proof are versions of the publication after peer review.

- The final published version features the final layout of the paper including the volume, issue and page numbers.

Link to publication

\footnotetext{
General rights rights.

- You may freely distribute the URL identifying the publication in the public portal. please follow below link for the End User Agreement:

www.umlib.nl/taverne-license

Take down policy

If you believe that this document breaches copyright please contact us at:

repository@maastrichtuniversity.nl

providing details and we will investigate your claim.
}

Copyright and moral rights for the publications made accessible in the public portal are retained by the authors and/or other copyright owners and it is a condition of accessing publications that users recognise and abide by the legal requirements associated with these

- Users may download and print one copy of any publication from the public portal for the purpose of private study or research.

- You may not further distribute the material or use it for any profit-making activity or commercial gain

If the publication is distributed under the terms of Article 25fa of the Dutch Copyright Act, indicated by the "Taverne" license above, 


\section{A temporal common ground for learning: The moderating effect of shared mental models on the relation between team learning behaviours and performance improvement}

\section{Catarina Marques Santos, Sjir Uitdewilligen \& Ana Margarida Passos}

To cite this article: Catarina Marques Santos, Sjir Uitdewilligen \& Ana Margarida Passos (2015) A temporal common ground for learning: The moderating effect of shared mental models on the relation between team learning behaviours and performance improvement, European Journal of Work and Organizational Psychology, 24:5, 710-725, DOI: 10.1080/1359432X.2015.1049158

To link to this article: https://doi.org/10.1080/1359432X.2015.1049158

\section{曲 Published online: 26 May 2015.}

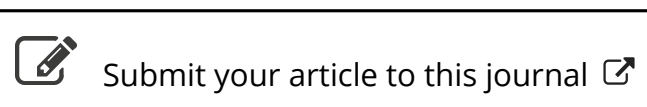

\section{Џlll Article views: 1483}

\section{Q View related articles $\longleftarrow$}

View Crossmark data ¿

Citing articles: 14 View citing articles $[7$ 


\title{
A temporal common ground for learning: The moderating effect of shared mental models on the relation between team learning behaviours and performance improvement
}

\author{
Catarina Marques Santos $\oplus^{1}$, Sjir Uitdewilligen $\oplus^{2}$, and Ana Margarida Passos $\oplus^{1}$ \\ ${ }^{1}$ Business Research Unit (BRU-IUL), Instituto Universitário de Lisboa (ISCTE-IUL), Lisbon, Portugal \\ ${ }^{2}$ Faculty of Psychology and Neuroscience, Department of Work and Social Psychology, Maastricht University, \\ Maastricht, The Netherlands
}

\begin{abstract}
In this longitudinal study, we integrated a team process and a learning curve perspective on team learning and empirically analysed whether team learning processes lead to performance improvement. In addition, we tested whether this relation is moderated by the similarity of team members' task, team, and temporal mental models. We tested our model on a sample of 67 teams (314 individuals) competing in a management simulation over five consecutive time periods, using random coefficient modelling (RCM). Our findings suggest that team learning behaviours do not have a direct effect on the team learning curve, but temporal and task mental models are crucial for the translation of team learning behaviours into performance improvement. We found that when teams have similar task and temporal mental models, engaging in team learning processes is beneficial, whereas, when teams have dissimilar task and temporal mental models, it is detrimental to performance improvement. We did not find a significant effect for the moderating role of team mental model similarity. Our study emphasizes the importance of integrating different perspectives on team learning and provides support for the role of team cognition as a catalyst for team learning.
\end{abstract}

Keywords: Team learning processes; Team learning outcomes; Mental models; Learning curves.

Team learning is essential for organizational teams that need to continuously adapt to changing environments and maintain high levels of performance (Edmondson, Dillon, \& Roloff, 2007; Rosen et al., 2011; Savelsbergh, Gevers, Van Der Heijden, \& Poell, 2012). Team learning has been investigated in the literature as a process and as a learning curve (Edmondson et al., 2007). Team learning processes involve behaviours such as asking questions, challenging assumptions, and discussing errors or unexpected outcomes (Edmondson, 1999; Savelsbergh, Van Der Heijden, \& Poel, 2009). Team learning curves are reflected in the trajectory of change in team performance over time (e.g., Edmondson et al., 2007; Pisano, Bohmer, \& Edmondson, 2001). Despite conceptual overlap, the process and learning curve perspectives on team learning have been studied in separate research streams. In this study, we combine these two perspectives in order to demonstrate how team learning processes are related to the trajectory of performance over time. Our study aims to demonstrate that team learning processes do not only have an immediate effect on performance but that teams increasingly benefit as they continue to interact and perform over time.

Additionally, scholars have begun to question whether there may be boundary conditions to the positive effects of engaging in team learning processes (e.g., Bunderson \& Sutcliffe, 2003a; Edmondson, 2003; Fiol $\&$ Lyles, 1985). Team learning is a resource intense and socially sensitive process that may detract from core task performance and can result in conflict and tension among the team members (Bunderson \& Sutcliffe, 2003a). We propose that shared mental models (i.e., a shared understanding among team members regarding the relevant aspects of the team task; Klimoski \& Mohammed, 1994) may constitute a critical factor that may determine under what conditions team learning processes may be beneficial. Therefore, we pose that

Correspondence should be addressed to Catarina Marques Santos, Instituto Universitário de Lisboa (ISCTE-IUL), Avenida das Forças Armadas, Edifício ISCTE, BRU-IUL, Sala 2W8, 1649-026 Lisbon, Portugal. E-mail: catarina_marques_santos@iscte.pt.

No potential conflict of interest was reported by the authors.

This work was supported by the Portuguese Foundation for Science and Technology (FCT) [grant number SFRH/BD/79292/2011]. 
only when teams start with a basic common ground (i.e., share a mental model), they will be able to translate team learning processes into performance improvement.

With this study, we aim to contribute to the team learning and team cognition literature in three important ways. First, although a number of authors have posited that more research on how team functioning enfolds over time is needed (e.g., Bliese \& Ployhart, 2002; Cronin, Weingart, \& Todorova, 2011; Pitariu \& Ployhart, 2010; Roe, Gockel, \& Meyer, 2012), as yet, evidence is lacking for this longitudinal effect of team learning on team performance improvement. Our longitudinal design allows us to understand this longitudinal effect. Second, by investigating the effect of team learning processes on the increase of team performance over time, we integrate the, as yet, separately developed notions of team learning processes and team learning curves. Third, by identifying shared mental models as an important boundary condition for team learning, we shed light on the question of under what conditions team learning processes actually lead to performance improvement. In addressing these gaps, our study aims to provide insights about how teams function and perform over time.

\section{THE RELATIONSHIP BETWEEN TEAM LEARNING PROCESSES AND TEAM PERFORMANCE IMPROVEMENT}

Although there are different conceptualizations of team learning processes (e.g., Schippers, Homan, \& Van Knippenberg, 2013; Wilson, Goodman, \& Cronin, 2007), we follow the one by Edmondson (1999). This approach refers to team learning processes as a combination of behaviours, including reflection on processes and outcomes, discussion of important issues, exploration of different perspectives, experimentation with new working methods, analysis and communication of errors, and coconstruction of meaning (Edmondson, 1999; Savelsbergh et al., 2009). An important component of team learning processes is team reflexivity-by which team members collectively look back and discuss the team's objectives, strategies, and processes, which helps them to identify potential problems, and to find causes and solutions, and prepare for future action (Schippers et al., 2013; West, 2000). By engaging in learning processes, teams can adapt their strategy and procedures and improve their working methods for subsequent performance episodes (Moreland \& McMinn, 2010; Savelsbergh et al., 2009; Schippers, Den Hartog, Koopman, \& Van Knippenberg, 2008). Further, team members can improve their interaction processes, detect and make sense of errors, and prevent the team from making the same mistakes in subsequent task performance episodes (Schippers, Den Hartog, \& Koopman, 2007; Van Dyck, Frese, Baer, \& Sonnentag, 2005). Team learning process research has typically employed an input-process-output model, in which team learning behaviours mediate the relationship between relatively stable team or contextual characteristics and team outcomes (e.g., Edmondson, 1999; Wong, 2004).

Team performance improvement is most accurately portrayed by team learning curves (Mathieu \& Rapp, 2009). Team learning curves show the temporal trajectory of team performance over time from the beginning of a new product or process. Team learning curves have been studied mainly in operational settings, such as manufacturing or health care, where accumulated experience with a task has been consistently linked with improvement in team efficiency (Edmondson et al. 2007). When experience with the task accumulates, teams develop routines and procedures that enable them to reduce the time required to complete their tasks and improve the quality of their performance (e.g., Pisano et al., 2001). Previous research shows that not only the individual experience of the team members matters, but also the experience the members accumulate in working on the task as a team (Reagans, Argote, \& Brooks, 2005). For instance, studies by Pisano and colleagues (2001) and Edmondson, Winslow, Bohmer, and Pisano (2003) showed that cardiac surgery teams gradually improved their efficiency after implementing a new surgical procedure. Moreover, they found that teams varied in the rate at which they learnt to use the new technology.

A number of variables have been identified that impact team learning curves, including task experience and team stability (Edmondson et al., 2003; Pisano et al., 2001; Reagans et al., 2005). However, research on the role of team learning processes on performance improvement is still scarce. Research on individual expertise development suggests that it is not simply the amount of experience with a task but a specific type of dedicated practice that predicts performance increase (Ericsson, Krampe, \& Tesch-Römer, 1993). Team learning process is a bottom-up emergent phenomenon that originates at the individual level and emerges through team member interactions, as a team-level construct (Costa et al., 2013; Kozlowski \& Chao, 2012; Kozlowski, Chao, \& Jensen, 2010; Kozlowski \& Klein, 2000). At the individual level, team members acquire knowledge, skills, and performance capabilities that are necessary to accomplish their individual tasks (Kozlowski, Gully, Nason, \& Smith, 1999). Subsequently, team members learn how their task is related to the tasks of the other members. In order to achieve this higher compilation of knowledge, team members have to engage in purposeful interpersonal interactions aimed at gaining an understanding of their teammates' roles and capabilities (Pearsall, Ellis, $\&$ Bell, 2010). Thus, to develop effective interaction processes, team members should engage in processes of communication, reflection, exchange, observation, 
and collaboration (Kozlowski \& Bell, 2008; Kozlowski $\&$ Chao, 2012). The outcomes of the team learning processes emerge as a pool of declarative as well as procedural knowledge shared among the members of the team and is generally considered to lead to an increase in team performance over time (Edmondson, 1999; Savelsbergh et al., 2012; Wong, 2004).

To date, various studies have demonstrated a positive relation between team learning processes and team performance (e.g., Guchait \& Hamilton, 2013; Savelsbergh et al., 2009; Van Der Vegt \& Bunderson, 2005; Van Woerkom \& Croon, 2009). These studies suggest that by asking questions, seeking feedback, and reflecting on previous performance episodes, team members test their assumptions, discuss divergent opinions, and thereby achieve high levels of performance (Edmondson, 1999; Guchait \& Hamilton, 2013; Savelsbergh et al., 2009; Schippers, Den Hartog, Koopman, \& Wienk, 2003). However, because in these studies performance was only measured a single time, they cannot provide insight into the effects of team learning processes on the trajectory of team performance. Recently, Schippers and colleagues (2013) conducted a study with business students working on their bachelor thesis over 10 months where they measured team learning and team performance twice. Their findings showed a mediating effect of team learning at Time 2 between the interaction of initial team performance and team reflexivity at Time 2 on final performance, controlling for Time 1 team learning and reflexivity (Schippers et al., 2013). However, in order to assess and predict between-team variations in performance trajectories, such as the slope, at least three data points in time are required (Ployhart \& Vandenberg, 2010). Therefore, the previous studies can only show that team learning is associated with high performance but not that learning behaviours are related to the trajectory of performance over time.

We posit that team learning processes are likely to foster not only immediate team performance but also an increase in team performance over time. Discussing errors about previous tasks helps members to detect faults in their performance routines, improve their strategies, and work more effectively on subsequent tasks (Edmondson, 1999; Savelsbergh et al., 2009). Thus, over time, teams that engage in learning behaviours are likely to develop their collective understanding of the task and optimize the coordination of team members' actions, which lead to improvement in team functioning indicated by a positive performance trajectory (Edmondson et al., 2007).

Hypothesis 1: The extent to which the team members engage in team learning processes is positively related to team performance improvement.

\section{SHARED MENTAL MODELS AS A CATALYST FOR TEAM LEARNING}

Several studies indicate that the extent to which teams engage in team learning processes is positively related to team performance (Guchait \& Hamilton, 2013; Savelsbergh et al., 2009; Wong, 2004); however, these processes may not always translate into team performance improvement (Bunderson \& Sutcliffe, 2003a; Edmondson, 2003; Fiol \& Lyles, 1985; Kozlowski et al., 2010). First, team learning behaviours are intense and consume time and cognitive resources (Bunderson \& Sutcliffe, 2003a, 2003b). The cognitive resources a team has at its disposal for performing tasks are limited (Barnes et al., 2008; Kanfer \& Ackerman, 1989). When teams allocate their cognitive resources away from their assigned tasks, for instance, to engage in team learning behaviours, or to reflect about their work, team members make an additional effort representing an extra cost for their cognitive resources (Bunderson \& Sutcliffe, 2003a). Therefore, when team members exert efforts on team learning processes, it is crucial that they spend their resources efficiently; otherwise, team performance is likely to suffer. Further, teams that engage in team learning behaviours may abandon adequate solutions and choose untested approaches without gaining benefits (Barnes et al., 2008; MacMillan, Entin, \& Serfaty, 2004). This may create too much variation in teams' alternatives that cannot be effectively assimilated by team members and may consequently harm team performance (Bunderson \& Sutcliffe, 2003a, 2003b). Finally, engaging in team learning behaviours can be challenging for team members and may involve interpersonal risk taking (Edmondson, 2003). Particularly, when team members have diverging perceptions on central aspects of the task, they may not be willing to ask questions, seek information, or admit mistakes (Edmondson, 2003). Thus, when team members do not have similar mental models, team learning behaviours may be ineffective and time consuming, which hinders team performance improvement.

Several scholars have noted that team cognition, and in particular shared mental models, may have a critical function in the relation between team learning processes and team performance (e.g., Decuyper, Dochy, \& Van Den Bossche, 2010; Tindale, Smith, Thomas, Filkins, \& Sheffey, 1996; Tindale, Stawiski, \& Jacobs, 2008). Shared mental models refer to a common understanding by the team members regarding task, team, and temporal aspects of their work (Klimoski \& Mohammed, 1994; Mohammed, Ferzandi, \& Hamilton, 2010). Shared task mental models refer to a similar understanding among the team members about work objectives, team resources, and task duties (Mathieu, Heffner, Goodwin, Salas, \& Cannon-Bowers, 2000; Mohammed et al., 2010). Shared team mental models refer to a shared understanding regarding interpersonal interaction, and 
team members'skills (Mathieu et al., 2000; Mohammed et al., 2010). Shared temporal mental models refer to a similar understanding about the sequencing of the separate elements of the team task, the pacing with which activities should take place, and the deadlines for task accomplishment (Standifer \& Bluedorn, 2006).

A wide variety of studies indicates that when team members have similar mental models, they are likely to achieve high performance levels because they are able to accomplish the tasks efficiently without the need for explicit coordination and communication (DeChurch \& Mesmer-Magnus, 2010). What is more, when team members have a similar mental model, they will interpret changes in the task environment in a compatible way (Cannon-Bowers, Salas, \& Converse, 1993). This enables them to anticipate the needs and actions of other members while dealing with these changes (DeChurch \& Mesmer-Magnus, 2010; Gevers, Rutte, \& Van Eerde, 2006; Rico, Sánchez-Manzanares, Gil, \& Gibson, 2008). Further, when teams have similar mental models, they are on the same page regarding the functioning of the team, the team's strategy, and when deadlines have to be met (Mohammed et al., 2010; Mohammed \& Nadkarni, 2014). This is likely to facilitate the synchronization of learning processes among the team members, enable efficient communication, and ensure that the learning processes are aligned with collectively agreed upon goals (Gevers et al., 2006; Kozlowski \& Chao, 2012). In contrast, when team members do not have similar mental models, team learning may lead to misunderstandings, process loss, and frustration among the team members. Therefore, we expect that when team members have a similar mental model, this constitutes a fertile breeding ground for team learning to occur (Tindale et al., 2008). Sharing a mental model promotes effective team learning processes and the positive trajectory of team performance because "the more knowledge that team members share in common, the better able they are to apply it to solving the problem or making the decision" (Kozlowski \& Chao, 2012, p. 343). Similar mental models ensure that team members can quickly make sense of suggestions made by their teammates, that they discuss information, strategies, and problems that are aligned with the team goals, and that they provide each other with appropriate feedback at the right moment in time (Tindale et al., 2008).

\section{Shared task, team, and temporal mental models and team learning}

We expect that all three dimensions of mental models moderate the relationship between team learning processes and performance improvement. When teams share a task mental model they have a similar understanding about how the task should be accomplished in terms of procedures and practices, as well as about the resources needed to accomplish the task (Cannon-
Bowers et al., 1993). Previous research shows that a shared understanding of the information elaboration requirements of the task is related to the quality of information sharing among the team members (Van Ginkel, Tindale, \& Van Knippenberg, 2009). Team members that have a similar task mental model are more likely to communicate information in a way that is understood by the recipients (Fussell \& Krauss, 1989; Krauss \& Fussell, 1991). For instance, when a team member suggests a novel idea, the other members can directly make sense of this as they can place it into their own mental schema. In contrast, when team members have strongly divergent task mental models, they are more likely to misunderstand each other or require extensive communication in order to make sense of each other's ideas and suggestions (Cronin \& Weingart, 2007). In addition, a shared task mental model ensures that team members agree on what issues are central to task accomplishment. This ensures that team learning processes will be directed at issues that are considered important by all team members. Thus, shared task mental models facilitate team learning behaviours by ensuring that feedback and suggestions provided by team members are aligned with the team goals and are easily communicated and understood by the other members.

Hypothesis 2a: The relationship between team learning processes and team performance improvement is moderated by task mental model similarity in such a way that when team members have a similar task mental model, the relationship will be more positive than when they do not have a similar mental model.

When team members have a shared team mental model, they have a similar understanding about the team interaction, their responsibilities, the relation between their roles, and the knowledge, skills, and abilities of each team member (Cannon-Bowers et al., 1993). A shared understanding among the team members on how to interact with each other is likely to facilitate a variety of team processes. Previous studies have found a positive relation between shared team mental models and team processes, including communication and coordination (e.g., Mathieu et al., 2000). Given that team learning processes are in essence communication behaviours (Savelsbergh et al., 2009), they are likely to benefit from shared team mental models as well. Moreover, a clear understanding by team members of the distribution of roles and responsibilities in the team can increase the efficiency of teams' learning efforts as each member can focus on the tasks he or she is most experienced with. In addition, when members' are aware of each other's strengths and weaknesses, this will enable them to understand which members may need help or feedback and which members may help the team to understand and overcome previous errors or 
unexpected outcomes. Thus, a shared team mental model provides team members with an agreed upon structure for the interaction and discussion processes that are central to team learning and provides an efficient task distribution for the learning process (Edmondson, 2003; Savelsbergh et al., 2009).

Hypothesis 2b: The relationship between team learning processes and team performance improvement is moderated by team mental model similarity in such a way that when team members have a similar mental model the relationship will be more positive than when they do not have a similar mental model.

Finally, when team members share a temporal mental model, members have a shared understanding about the sequencing of the teams' tasks, deadlines for task accomplishment, and the pacing at which activities should take place (Gevers et al., 2006; Standifer \& Bluedorn, 2006). A shared temporal mental model can enable a team to optimize the timing and synchronization of team learning processes. Suggestions and feedback that are relevant but not voiced at appropriate times are less likely to be picked up by other team members (Kulik \& Kulik, 1988). Moreover, given that sustainable team functioning depends on a careful balancing of exploitation activities-engaging in immediate task performance-and exploration activities - collectively improving task processes for future task activities - it is crucial that team members time their team learning behaviours in such a way that they do not interfere with core task performance (Bunderson \& Sutcliffe, 2003a; March, 1991; Mohammed \& Nadkarni, 2014). Therefore, when team members are on the same page regarding when deadlines have to be met, when tasks have to be executed, and when there is time for reflection, learning processes will be synchronized among the team members as well as with the ongoing requirements of the execution of the team tasks. The research model is represented in Figure 1.

\begin{abstract}
Hypothesis 2c: The relationship between team learning processes and team performance improvement is moderated by temporal mental model similarity in such a way that when team members have a similar temporal mental model the relationship will be more positive than when they do not have a similar temporal mental model.
\end{abstract}

\section{METHOD}

\section{Sample}

The sample of the study consisted of 67 teams (314 individuals) enrolled in a management simulation over a 5 -week period. The teams were composed of company managers $(45.6 \%)$, university students $(36.8 \%)$, or both $(17.6 \%)$. The teams consisted of three to five persons with an average team size of 4.67 persons $(S D=0.58)$. The majority of teams contained five persons (73.1\%). The average age was 30.3 years $(S D=7.35)$ and $73.5 \%$ of the participants were male.

\section{Simulation}

Data were collected from the participants of a national management and strategy simulation-Global Management Challenge $\mathbb{R}$. This simulation has been used by others researchers (e.g., Costa, Passos, \& Bakker, 2014; Marques-Quinteiro, Passos, \& Curral, 2014; Santos \& Passos, 2013). During the simulation, each team runs a fictitious company with the objective of getting the highest company share price on the simulated stock exchange. The simulation lasts 5 weeks. Teams manage the company by making decisions each week about marketing, production, personnel, purchasing, and finance. Each team has a leader chosen by the team members at the moment they enrolled for the simulation. For each week, the business simulation programme analyses and compares the decisions made by the competing

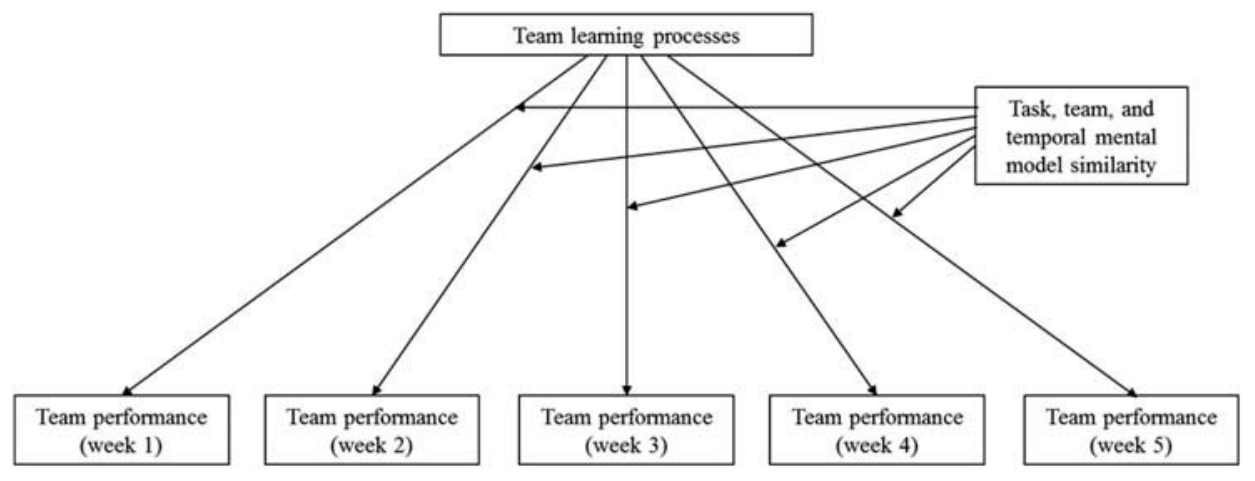

Figure 1. Hypothesized research model. 
teams, and calculates the share price of each enterprise and the ranking of teams. Then, the programme produces a management report for each team, showing detailed results in financial terms.

\section{Procedure}

Online questionnaires were sent to the team members by e-mail, two days after the beginning of the weekly task. A reminder was sent to the participants one day before the deadline to submit the weekly decision. The questionnaires were available until the moment in which teams had to submit their weekly decision. Participants individually answered the questionnaires before receiving the management report with the feedback about their decisions. This longitudinal procedure reinforces causality inferences (Mathieu \& Taylor, 2006) and reduces common-method variance (Brannick, Chan, Conway, Lance, \& Spector, 2010; Spector, 2006).

\section{Measures}

Shared mental models. To operationalize shared mental models, we used the procedure that is used most generally and considered the most valid in mental model research (DeChurch \& Mesmer-Magnus, 2010; Resick et al., 2010). We asked participants to evaluate the relatedness of sentences that describe team, task, and temporal procedures that are relevant for the team task, on a 7-point scale $(1=$ the sentences are not related and $7=$ the sentences are extremely related).

To operationalize the team mental models, we adapted four items of the mental model measure developed by Lim and Klein (2006). For the task and temporal mental models, we created-based on a detailed task analysis and with the help of the company developers of the simulation-four sentences that fit the specific task context. For the task mental model, we derived four sentences regarding the task aspects of the simulation, and for temporal mental models, we derived four sentences regarding the temporal aspects of the simulation (Mathieu \& Rapp, 2009; Uitdewilligen, Waller, \& Pitariu, 2013). Team members were asked to make paired comparisons among the four sentences of each dimension resulting in six comparisons for each dimension. A list of pairs of sentences is provided in the Appendix.

To assess the similarity of the mental models among the team members, we used UCINET (Borgatti, Everett, \& Freeman, 1992), following the procedure developed by Mathieu and colleagues (2000). This network-analysis programme provides a similarity measure based on Pearson's correlations ranging from -1 (completely dissimilar) to 1 (completely similar). We entered the relatedness scores of the team members into matrices for each team. Then we used UCINET to calculate the team similarity among the matrices of the team members.

Team learning processes. Team learning processes were measured using the scale of Savelsbergh and colleagues (2009) which covers eight dimensions: coconstruction of meaning, exploring different perspectives, error analysis, error communication, reflection on processes, reflection on outcomes, feedback seeking behaviour, and experimenting. We opted for this measure because it provides a comprehensive overall measure of team learning behaviours that fits well with the conceptualization of team learning we adopted from Edmondson (1999). The scale validation study by Savelsbergh et al. (2009) indicates that team learning can be operationalized as a second-order construct composed of the eight behavioural dimensions. As we aim to analyse the influence of team learning behaviours as a whole, we operationalized team learning as the average score of all items. Participants rated the extent to which they agreed with each sentence (e.g., "We encourage each other to look at our work from different perspectives") on a 7-point scale ( 1 = totally disagree; 7 = totally agree). Team learning was measured in the fourth week of the simulation. The Cronbach's alpha was .98. A second-order confirmatory factor analysis for the eight dimensions of team learning processes presents an acceptable, although not perfect, model fit: $\chi_{(292)}^{2}=1212.72, p=.00$; comparative fit index $=.88$; Tucker-Lewis index $=.87$; standard root mean square residual $=.05$.

Team performance. Team performance was operationalized as the share price in each week of the simulation. Share price was given in euros and was automatically calculated by the simulation. Share price is a complex outcome measure that combines the decisions on the distinct topics on which team members need to make decisions (e.g., production, finance, and marketing), and thereby captures the combined effort of the team as a whole.

Control variables. We included team size, task experience, and shared mental model accuracy as control variables in our analyses (Humphrey, Morgeson, \& Mannor, 2009). Team size can impact the team learning processes and the team's ability to develop mental models. We also controlled for task experience (participation in previous editions of the simulation) as this may impact mental models, team learning processes, and outcomes. In addition, we controlled for shared mental models accuracy (the extent to which the team members' mental models are similar to those of experts in the respective area; Edwards, Day, Arthur, \& Bell, 2006) as this may correlate with mental models similarity, and impact team learning processes and outcomes. Mental model accuracy was assessed by comparing the mental models of 
the team members to an expert model based on ratings of 12 participants who had won previous editions of the competition (Webber, Chen, Payne, Marsh, \& Zaccaro, 2000).

\section{Aggregation}

As the level of analysis in this study was the team level, the individual responses to the team learning questionnaire were aggregated to the team level for further analysis (Costa et al., 2013). We computed $R_{\mathrm{wg}(\mathrm{j})}$ indicators (James, Demaree, \& Wolf, 1993), designed for multipleitem scales, and intraclass correlation coefficients (ICCs) (Bliese, 2000) to justify aggregation. All the values were in accordance with the required criteria $\left(R_{\mathrm{wg}(\mathrm{j})}=0.83\right.$; $\left.\operatorname{ICC}(1)=0.19 ; \operatorname{ICC}(2)=0.52 ; F_{(66,246)}=2.09, p=.00\right)$.

\section{Data analysis}

To analyse our longitudinal data and test our hypotheses, we used RCM following the guidelines by Bliese and Ployhart (2002). RCM accounts for nonindependence of observations and for heteroscedasticity (inconsistency in the variance over time). In addition, it provides tests for intrateam and interteam change and enables the analyses of team performance trajectories (Bliese \& Ployhart, 2002). We estimated all our models in the statistical software R (version 3.1.1), an open source statistical software well suited for RCM (Culpepper \& Aguinis, 2011). We estimated the growth models by means of the Nonlinear and Linear Mixed Effects package written by Pinheiro and Bates (2000). We coded time as 0, 1, 2, 3, and 4 to represent weeks $1,2,3,4$, and 5 , respectively. In this way, we were able to interpret the intercept of our performance growth model as the performance score on the first trial (Bliese \& Ployhart, 2002). We grand-meancentred our dependent and independent variables to ease interpretation and enable cross-model comparison (Singer \& Willett, 2003).

\section{RESULTS}

Table 1 provides the means, standard deviations, and the correlations for all study variables at the team level. The results did not show significant correlations between performance and mental model similarity, nor between team learning processes and performance. Regarding the control variables, team size was negatively correlated with task and team mental model similarity $(r=-.27, p<.05$; $r=-.38, p<.01$, respectively). To test our hypotheses, we followed a number of steps divided into two levels. In level 1 , we established the fixed functions for time, and in level 2, we added predictors of intercept and slope variability to test our hypothesized relationships (Bliese \& Ployhart, 2002).

We examined the ICC(1) for the dependent variable, team performance, to determine the total amount of

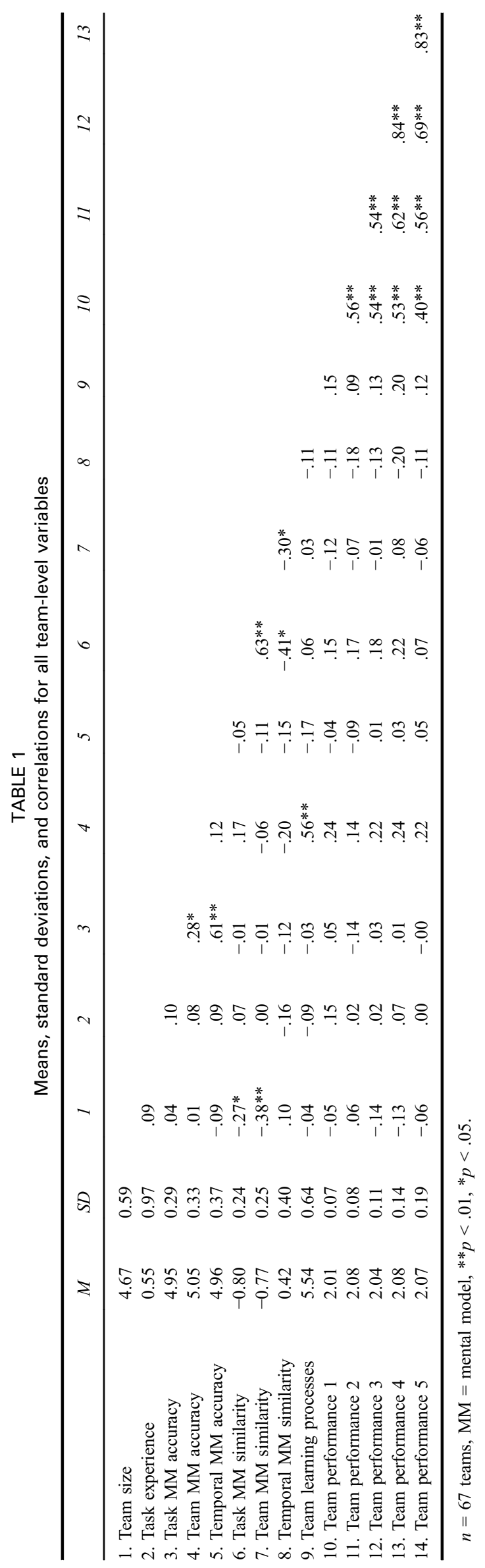


TABLE 2

Results of fixed function for time (Model 1), and of fitting random coefficient models to team performance (Models 2 and 3 )

\begin{tabular}{|c|c|c|c|c|c|c|c|c|c|}
\hline \multirow{2}{*}{$\begin{array}{l}\text { Parameter } \\
\text { Fixed effects }\end{array}$} & \multicolumn{3}{|c|}{ Model 1: linear function for time } & \multicolumn{3}{|c|}{ Model 2: random intercept } & \multicolumn{3}{|c|}{ Model 3: random intercept and slopes } \\
\hline & Estimate & $S E$ & $t$ & Estimate & $S E$ & $t$ & Estimate & $S E$ & $t$ \\
\hline Intercept & $2.03 * * *$ & 0.01 & 170.43 & $2.03 * * *$ & 0.01 & 146.12 & $2.03 * * *$ & 0.01 & 262.04 \\
\hline Time & $0.01 * *$ & 0.00 & 2.73 & $0.01 * * *$ & 0.00 & 3.97 & $0.01 * *$ & 0.01 & 2.58 \\
\hline \multicolumn{10}{|l|}{ Goodness of fit } \\
\hline-2 log-likelihood & 211.70 & & & 274.34 & & & 336.06 & & \\
\hline AIC & -417.41 & & & -540.68 & & & -660.12 & & \\
\hline BIC & -405.98 & & & -525.45 & & & -637.27 & & \\
\hline
\end{tabular}

variance that is attributable to between-team (over time) versus within-team differences (Bliese, 2000). The ICC (1) value for team performance was .27 , which means that $27 \%$ of the variance was attributable to betweenteam differences and $73 \%$ of the variance was attributable to within-team differences over time. As there is sufficient within-team variance, growth models are an appropriate technique for analysing these data (Bliese, 2000).

In order to test the average trajectory of team performance of all teams over time, we first determined the fixed relation between the variable time and team performance. The results indicate that the estimate of the linear function for time was positive and statistically significant ( $t=2.73, p<.01)$, suggesting that on average the teams showed an increase in performance scores. In addition to a linear effect, we also tested a quadratic effect of time on team performance. However, the quadratic function of time was not significant $(t=-1.66, p=.10)$.

Next, we analysed whether there is significant variance between the teams in the intercept and slope of performance over time. To determine variability in the growth parameters, we first added a random intercept term to our model to test between-team differences in the initial levels of team performance (see Table 2). This step aims to examine whether a random intercept model (i.e., teams significantly differ in their initial team performance level) fits our data better than a fixed intercept model. In order to establish the optimal model and most parsimonious model, we used chi-square difference (i.e., -2 log-likelihood ratios (-2LL)) to compare the more complex model with the baseline model (Bliese \& Ployhart, 2002). The comparison of the random-intercept model $(-2 \mathrm{LL}=274.34)$ with the baseline model $(-2 \mathrm{LL}=211.70)$ significantly improved the model fit $(\triangle 2 \mathrm{LL}=62.64, p<.001)$. This means that the model that allows teams to differ in their initial team performance fitted the data better than the model with a fixed intercept.

Second, we determined whether there was significant variability among teams in the rate of change in team performance (i.e., slope variation). The random-slope model (allowing for difference in the slope among teams) significantly improved upon the random-intercept model $(\Delta 2 \mathrm{LL}=61.72, p<.001)$. This suggests that the best model accounts for difference in team performance between teams at the beginning of the simulation, as well as for difference in the rate of change across teams.

In addition, we tested for autocorrelation and heteroscedasticity. The results revealed that the models in which we controlled for autocorrelation $(\Delta 2 \mathrm{LL}=0.02, p=.83)$ and heteroscedasticity $(\Delta 2 \mathrm{LL}=1.77, p=.17) \mathrm{did}$ not improve model fit. So, we did not control for autocorrelation and heteroscedasticity in the further analyses.

\section{Level 2 analyses: predictors of team performance trajectories}

In the first part of the RCM analyses, we determined the relationship between team performance and time. In this second part of the RCM analyses, we estimated a model that included team learning processes and the three dimensions of mental model similarity to predict variance in the trajectory parameters. All level-2 models include control variables for team size, task experience, and mental model accuracy.

Hypothesis 1 states that team learning processes are positively related to performance improvement. To test this hypothesis, we added team learning processes to the longitudinal model. The team learning processes were not significantly related to initial team performance $(y=-0.00, t=-0.13, p=.90)$ nor was the interaction between time and team learning processes $(y=0.01$, $t=0.81, p=.42$ ) (see Table 3). Thus, team learning processes did not have a positive main effect on initial team performance neither on performance improvement over time. Hypothesis 1 is not supported.

Hypothesis 2 predicts that the relationship between team learning processes and team learning outcomes over time is moderated by mental models similarity. To test this hypothesis, the interaction terms of team learning processes with the three types of mental models were added to the model. For the task dimension of mental 
TABLE 3

Results of team learning processes predicting team performance (Model 4)

\begin{tabular}{|c|c|c|c|}
\hline \multirow{2}{*}{$\begin{array}{l}\text { Predictor } \\
\text { Fixed effects }\end{array}$} & \multicolumn{3}{|c|}{ Model 4} \\
\hline & Estimate & $S E$ & $t$ \\
\hline Intercept & $2.05 * * *$ & 0.06 & 31.81 \\
\hline Time & $0.01 *$ & 0.01 & 2.45 \\
\hline Team size & -0.01 & 0.01 & -0.42 \\
\hline Task experience & 0.01 & 0.01 & 0.88 \\
\hline Task MM accuracy & -0.00 & 0.04 & -0.12 \\
\hline Team MM accuracy & 0.04 & 0.03 & 1.25 \\
\hline Temporal MM accuracy & -0.02 & 0.03 & -0.64 \\
\hline Team learning processes & -0.00 & 0.02 & -0.13 \\
\hline Time $\times$ team learning processes & 0.01 & 0.01 & 0.81 \\
\hline \multicolumn{4}{|l|}{ Goodness of fit } \\
\hline-2 log-likelihood & 310.77 & & \\
\hline $\mathrm{AIC}$ & -595.53 & & \\
\hline $\mathrm{BIC}$ & -546.51 & & \\
\hline
\end{tabular}

models, the results showed that the interaction term involving time, team learning processes, and task mental model similarity was significant $(y=0.13, t=2.10$, $p=.04$ ) (see Table 4). This interaction is depicted in Figure 2. For teams that have a similar task mental model, the extent to which teams engage in team learning processes is related to their initial performance level, whereas for teams that do not have a similar task mental model, this is not the case. Further, the performance level increases over time when teams have a similar task mental model and engage in many learning behaviours. When teams engage in many learning processes and have a dissimilar task mental model, their performance slightly decreases over time. Thus, when teams have a common ground, team learning is beneficial for performance, but when teams do not have a common ground, team learning is detrimental to performance. These results provide support for Hypothesis $2 \mathrm{a}$.

For the team dimension of mental models, the results showed that the interaction term involving time, team learning processes, and team mental model similarity was not significant $(y=-0.04, t=-60, p=.55$ ) (see Table 4). These results do not support Hypothesis $2 \mathrm{~b}$.
TABLE 4

Results of main and interaction effects of task, team, and temporal mental model similarity predicting team performance (Model 5)

\begin{tabular}{|c|c|c|c|}
\hline \multirow{2}{*}{$\frac{\text { Predictors }}{\text { Fixed effects }}$} & \multicolumn{3}{|c|}{ Model 5} \\
\hline & Estimate & $S E$ & $t$ \\
\hline Intercept & $2.08^{* * *}$ & 0.07 & 30.52 \\
\hline Time & $0.01 * *$ & 0.01 & 2.77 \\
\hline Team size & -0.01 & 0.01 & -0.85 \\
\hline Task experience & 0.01 & 0.01 & 0.86 \\
\hline Task MM accuracy & 0.01 & 0.04 & 0.24 \\
\hline Team MM accuracy & 0.02 & 0.03 & 0.61 \\
\hline Temporal MM accuracy & -0.04 & 0.03 & -1.26 \\
\hline Team learning processes & -0.00 & 0.02 & 0.04 \\
\hline Time $\times$ team learning processes & -0.00 & 0.01 & -0.09 \\
\hline Task MM similarity & $0.12^{*}$ & 0.05 & 2.20 \\
\hline Team MM similarity & $-0.12 *$ & 0.06 & -2.00 \\
\hline Temporal MM similarity & -0.02 & 0.02 & -0.93 \\
\hline Time $\times$ task MM similarity & -0.00 & 0.03 & -0.13 \\
\hline $\begin{array}{l}\text { Team learning processes } \times \text { task } \mathrm{MM} \\
\text { similarity }\end{array}$ & 0.07 & 0.10 & 0.74 \\
\hline $\begin{array}{l}\text { Time } \times \text { team learning processes } \times \text { task MM } \\
\text { similarity }\end{array}$ & $0.13^{*}$ & 0.06 & 2.10 \\
\hline Time $\times$ team MM similarity & 0.01 & 0.03 & 0.27 \\
\hline $\begin{array}{l}\text { Team learning processes } \times \text { team } \mathrm{MM} \\
\text { similarity }\end{array}$ & 0.07 & 0.10 & 0.72 \\
\hline $\begin{array}{l}\text { Time } \times \text { team learning processes } \times \text { team } \\
\text { MM similarity }\end{array}$ & -0.04 & 0.06 & -0.60 \\
\hline Time $\times$ temporal MM similarity & -0.01 & 0.01 & -0.52 \\
\hline $\begin{array}{l}\text { Team learning processes } \times \text { temporal MM } \\
\text { similarity }\end{array}$ & 0.00 & 0.03 & 0.02 \\
\hline $\begin{array}{l}\text { Time } \times \text { team learning processes } \times \text { temporal } \\
\text { MM similarity }\end{array}$ & $0.07 * * *$ & 0.02 & 3.16 \\
\hline \multicolumn{4}{|l|}{ Goodness of fit } \\
\hline-2 log-likelihood & 292.49 & & \\
\hline $\mathrm{AIC}$ & -534.98 & & \\
\hline BIC & -441.64 & & \\
\hline
\end{tabular}

$n=67$ teams, $\mathrm{MM}=$ mental model, ${ }^{* * *} p<.001,{ }^{*} p<.01,{ }^{*} p<.05$.

For the temporal dimension of mental models, the result showed that the interaction term involving time, team learning processes, and temporal mental model similarity was significant $(y=0.07, t=3.16, p=.00)$. There is a positive linear trend for the interaction effect between the three variables on team performance (see Table 4). Figure 3 shows the interaction between time,
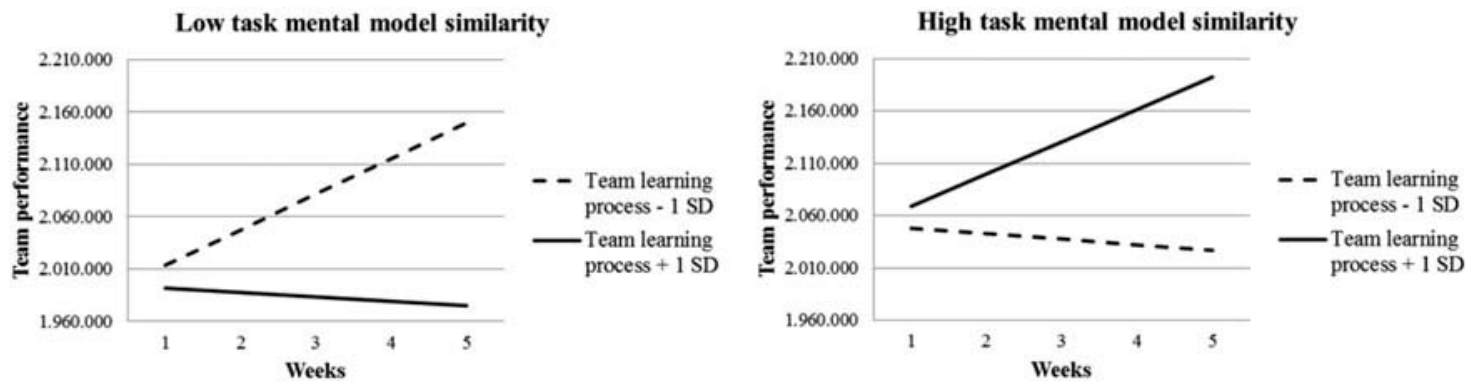

Figure 2. The interaction effect between team learning processes and task mental model similarity on team performance. 

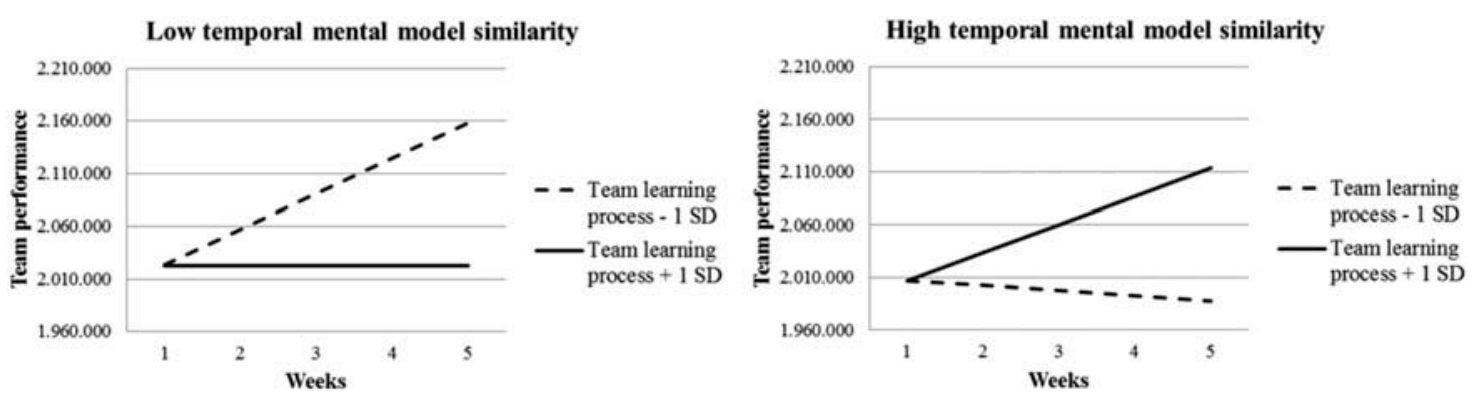

Figure 3. The interaction effect between team learning processes and temporal mental model similarity on team performance.

low and high levels of temporal mental model similarity (respectively), and team performance. When teams have a similar temporal mental model and engage in many team learning processes, team performance increases over time. When teams have a similar temporal mental model and engage in few learning behaviours, team performance decreases over time. However, when teams have a dissimilar temporal mental model and engage in few learning processes, the performance level increases over time. When teams have a dissimilar temporal mental model and engage in many learning processes, their performance is stable over time. Thus, when teams have a temporal common ground, team learning is beneficial to performance, but when teams do not have a temporal common ground, team learning is detrimental to performance. These results provide support for Hypothesis 2c.

\section{DISCUSSION}

When does engaging in team learning processes benefit team performance improvement? We found that when task and temporal mental model similarity were high, the extent to which teams engaged in collective learning processes was positively related to team performance improvement. However, when task and temporal mental model similarity were low, this pattern reversed, so that learning processes negatively contributed to performance improvement. We did not find a significant effect for the moderating role of team mental model similarity. We tested our hypotheses in a longitudinal study with five measurement points for team performance and the model variables measured at different moments in time. Our findings offer meaningful contributions to the team learning as well as the team cognition literature, and emphasize the importance of longitudinal studies for providing insight into how teams learn and develop over time.

Our primary contribution lies in identifying shared cognition as an important boundary condition for the effect of team learning processes on the development of team performance over time. Thereby, we tie into the debate on whether engaging in collective learning process is always beneficial for team performance improvement.
A number of studies have shown that team learning is beneficial for team performance (e.g., Edmondson, 1999; Guchait \& Hamilton, 2013; Savelsbergh et al., 2009). However, recently, Bunderson and Sutcliffe (2003a) questioned whether team learning behaviours are always beneficial for team performance. In a related vein, Moreland and McMinn (2010) wondered what conditions have to be met for team reflexivity to have identifiable effects on performance. We found that team performance only increases over time when teams engage in team learning processes and have similar task and temporal mental models. In order to effectively discuss ideas, analyse errors, and process feedback, team members need to be on the same page regarding the team strategy, deadlines for task accomplishment, and the pacing at which activities take place (Cannon-Bowers et al., 1993; Gevers et al., 2006; Standifer \& Bluedorn, 2006). Lack of shared understanding may lead members to experience task conflict-intragroup disputes related to the content of the tasks, such as differences regarding ideas or opinions (Jehn, 1995), and temporal conflict-intragroup disagreements about time, the duration of a task, and the length of time the team should spend on a specific task or goal (Mohammed \& Nadkarni, 2011; Standifer et al., 2015). So, without common ground, learning processes may lead to frustration and disagreements, which prevent teams from achieving increasing levels of performance over time.

The finding that team members need to have similar mental models in order to benefit from team learning is in accordance with a resource allocation perspective on team functioning (Barnes et al., 2008; Kanfer \& Ackerman, 1989). Team learning is a resource-intensive process that detracts from core task performance and that consumes time and cognitive resources (Bunderson \& Sutcliffe, 2003a, 2003b). Team members have to divide their resources between exploitation activities and exploration activities (March, 1991). When team members have similar mental models, their core task performance will run smoothly (Mohammed et al., 2010) and they will consequently have spare resources that can be used for exploration. In addition, their learning activities will require few resources as team members will be able to effectively communicate ideas for process 
improvement (Fussell \& Krauss, 1989) and to optimally time and synchronize their improvement-directed interactions (Mohammed \& Nadkarni, 2014). In contrast, when team members lack such common ground, engaging in team learning processes constitutes an extra effort (Bunderson \& Sutcliffe, 2003a), that may overtax the resources available to the team. Thus, for teams that do not share task and temporal mental models, it may at times be better to focus on core task performance because engaging in both exploration and exploitation may be unattainable.

Our research also advances knowledge about the differential effects of the different dimensions of shared mental models. Whereas task and temporal mental model similarity led to team performance improvement when combined with team learning behaviours, team mental model similarity did not. A possible explanation could be that the three dimensions of mental models did not develop at the same pace and that the development of one mental model dimension may influence the development of the other dimensions (Maynard \& Gilson, 2014). In contexts where team members need to work on the task from the early beginning of the team life cycle and where deadlines are particularly important for team performance, team members may neglect the interpersonal aspects of teamwork, such as communication, trust, and mutual support. Therefore, the development of temporal and task mental models may precede and influence the development of team mental models and the team mental models may not yet be fully crystallized at the middle of the team life cycle. Alternatively, teams may require a shared understanding about the team, the task, and the temporal aspects of work at different moments in the team's life cycle (Hackman \& Wageman, 2005). For instance, it could be that team mental model similarity may be more important at the beginning instead of halfway the team life cycle.

It is also possible that agreement among the team members on the team dimension is less crucial for team learning than agreement on the task and temporal dimensions. Team members may improve their task performance and discuss with each other despite some divergence in their understanding regarding how they should interact with each other. As learning behaviours often specifically focus on how the members can improve their interactions, team mental models may be more typically modelled as an outcome instead of a facilitator of team learning. So it may be more fluid than task and temporal mental models as it changes when team members develop new insights and procedures (Cannon-Bowers et al., 1993). In addition, extant research suggests that when interaction patterns are overtly rigid, this may actually hinder teams in adapting to novel events (e.g., Stachowski, Kaplan, \& Waller, 2009). In accordance with this notion, a recent study found task mental models, but not team mental models, to have a positive effect on team performance (Guchait
\& Hamilton, 2013). Another explanation for the divergent finding regarding team mental models may be related to the outcome variable under consideration. Although the team dimension of mental models has been related to team performance (Cannon-Bowers et al., 1993; Mathieu et al., 2000; Santos \& Passos, 2013), this dimension may be more important for the translation of team learning behaviours into affective outcomes, such as satisfaction and viability (Hackman, 1987).

Finally, our research emphasizes the importance of longitudinal studies for analysing team dynamics over time. Researchers have posited that longitudinal studies are needed to understand "what happens in teams" (Roe et al., 2012) or "when things happen" (Sonnentag, 2012). Longitudinal studies are needed to analyse the dynamic interrelations between coevolving constructs and to capture how teams form and develop, function, and perform over time. Although "teams can neither be defined nor understood without reference to time" (Roe et al., 2012, p. 630), researchers have still mainly analysed teams in a static way. The present study takes a temporal perspective by analysing how team performance increases over time and which variables explain this increase (Ployhart \& Vandenberg, 2010; Roe, 2008). So far, researchers have analysed the effects of team learning behaviours on average team performance or team performance at the end of the team life cycle; however, this approach may misrepresent the true effects of learning over time. For instance, high initial team performance may confound the relationship between learning processes and average performance. Thus, our study points to the possibility that the relationships found between variables in crosssectional analysis may not hold when we look at dynamic trajectories of the outcome variable over time.

\section{Practical implications}

It becomes increasingly important for organizations to ensure that teams are able to constantly learn and improve their performance. Teams play a crucial role in helping organizations to compete with other organizations and to survive in challenging environments. Our results suggest that from the beginning of the team life cycle, members need to share an understanding about the task and temporal aspects of their work in order to translate team learning processes into performance growth. Previous research suggests that the development of such common ground may be facilitated when teams engage in planning sessions or develop team charters prior to team performance and when they engage in debriefings after performance episodes (Mathieu \& Rapp, 2009; Stout, Cannon-Bowers, Salas, \& Milanovich, 1999; Vashdi, Bamberger, \& Erez, 2013). Although when left to themselves, teams often do not take the time to explicitly discuss issues, such as how the task needs to be accomplished in terms of procedures 
and practices, what deadlines they will need to accomplish the tasks, and at what pace activities should take place, this may actually be crucial for developing a shared understanding and improving performance in the long run (Cannon-Bowers et al., 1993; Gevers et al., 2006; Standifer \& Bluedorn, 2006). Team leaders can play an important role, as well, in promoting shared mental models and effective team learning behaviours (Edmondson, 1999; Marks, Zaccaro, \& Mathieu, 2000). Team leaders play a crucial role in stimulating team members to reflect about the processes they use to accomplish the tasks, to seek and give feedback, and to discuss errors and unexpected outcomes (Schippers et al., 2008).

\section{Limitations and directions for future research}

A limitation of the present study was that team learning processes and shared mental models were measured only once around the middle of the team life cycle. Although prior research has shown the importance of mid-points in team projects for team development (Gersick, 1988), it could be important to measure both variables repeatedly in order to trace how the (co)evolution of team learning behaviours and mental models impact team performance outcomes. Moreover, we cannot be sure if we optimally timed our measure of team learning processes; it is possible that the effectiveness of these processes decrease from the middle of the team life cycle. Effective team learning processes at the beginning may promote the positive trajectory of team learning outcomes because teams need to establish a solid foundation from the early stages in order to promote effective team processes and performance (Ericksen \& Dyer, 2004; Mathieu \& Rapp, 2009). Therefore, future studies could benefit from a more fine-grained measurement of team learning processes and mental models at different moments in the team life cycle.

In this study, team learning outcomes were inferred from changes in team performance. Although this is a common way to assess team learning outcomes, an alternative approach could be the assessment of changes in team knowledge behaviours and attitudes (Kozlowski \& Ilgen, 2006; Kraiger, Ford, \& Salas, 1993). Future studies should analyse changes in team knowledge that show that team learning has occurred, such as the development of technical or motor skills, the decrease of errors, and the increase of automaticity in teams (Kraiger et al., 1993).

Finally, a limitation may be that we focused on the quality of team decisions, and not on the speed. In many contexts, decision speed may constitute a crucial component of team performance. As similarity in temporal mental models may have an impact particularly on the speed with which teams make decisions, future studies should not only analyse the accuracy but also the timeliness of team decision making (e.g., whether they submit their decisions long before the deadline, or a short time before the deadline) (Beersma et al., 2003).

\section{CONCLUSION}

Research on team learning processes has developed in relative isolation from research on team learning curves (Edmondson et al., 2007). Although many studies implicitly assume that when teams engage in learning processes, this will have a positive impact on the trajectory of team performance, an empirical study using longitudinal performance data to test this notion was lacking. Interestingly, the current study shows that team learning processes do not automatically lead to performance improvement. Our findings suggests that in order to achieve an increase in team performance over time, teams need to complement their team learning behaviours with shared task and temporal mental models. These findings stress that a strong cognitive foundation is crucial for teams in order to hone their skills and maintain competitive over time.

\section{ORCID}

Catarina Marques Santos (D) http://orcid.org/0000-0001-50908840

Sjir Uitdewilligen (D) http://orcid.org/0000-0001-7815-1579

Ana Margarida Passos (D) http://orcid.org/0000-0003-49664468

\section{REFERENCES}

Barnes, C. M., Hollenbeck, J. R., Wagner, D. T., DeRue, D. S., Nahrgang, J. D., \& Schwind, K. M. (2008). Harmful help: The costs of backing-up behavior in teams. Journal of Applied Psychology, 93, 529-539. doi:10.1037/0021-9010.93.3.529

Beersma, B., Hollenbeck, J. R., Humphrey, S. E., Moon, H., Conlon, D. E., \& Ilgen, D. R. (2003). Cooperation, competition, and team performance: Toward a contingency approach. The Academy of Management Journal, 46, 572-590. Retrieved from http://www. jstor.org/stable/30040650

Bliese, P. D. (2000). Within-group agreement, non-independence, and reliability: Implications for data aggregation and analysis. In K. J. Klein \& S. W. J. Kozlowski (Eds.), Multilevel theory, research, and methods in organizations (pp. 349-381). San Francisco, CA: Jossey-Bass.

Bliese, P. D., \& Ployhart, R. E. (2002). Growth modeling using random coefficient models: Model building, testing, and illustrations. Organizational Research Methods, 5, 362-387. doi:10.1177/ 109442802237116

Borgatti, S., Everett, M. G., \& Freeman, L. C. (1992). UCINET IV network analysis software. Columbia, MO: Analytic Technologies.

Brannick, M. T., Chan, D., Conway, J. M., Lance, C. E., \& Spector, P. E. (2010). What is method variance and how can we cope with it? A panel discussion. Organizational Research Methods, 13, 407420. doi:10.1177/1094428109360993

Bunderson, J. S., \& Sutcliffe, K. M. (2003a). Management team learning orientation and business unit performance. Journal of Applied Psychology, 88, 552-560. doi:10.1037/0021-9010.88.3.552

Bunderson, J. S., \& Sutcliffe, K. M. (2003b). When to put the brakes on learning. Harvard Business Review, 81, 20-21. 
Cannon-Bowers, J. A., Salas, E., \& Converse, S. (1993). Shared mental models in expert team decision-making. In N. J. Castellan Jr. (Ed.), Individual and group decision-making: Current issues (pp. 221246). Hillsdale, NJ: Lawrence Erlbaum.

Costa, P., Passos, A. M., \& Bakker, A. (2014). Empirical validation of the team work engagement construct. Journal of Personnel Psychology, 13, 34-45. doi:10.1027/1866-5888/a000102

Costa, P. L., Graça, A. M., Marques-Quinteiro, P., Santos, C. M., Caetano, A., \& Passos, A. M. (2013). Multilevel research in the field of organizational behavior: An empirical look at 10 years of theory and research. SAGE Open, 1-17. doi:10.1177/2158244013498244.

Cronin, M. A., \& Weingart, L. R. (2007). Representational gaps, information processing, and conflict in functionally diverse teams. Academy of Management Review, 32, 761-773. doi:10.5465/ AMR.2007.25275511

Cronin, M. A., Weingart, L. R., \& Todorova, G. (2011). Dynamics in groups: Are we there yet? The Academy of Management Annals, 5, 571-612. doi:10.1080/19416520.2011.590297

Culpepper, S. A., \& Aguinis, H. (2011). R is for revolution: A cuttingedge, free, open source statistical package. Organizational Research Methods, 14, 735-740. doi:10.1177/1094428109355485

DeChurch, L. A., \& Mesmer-Magnus, J. R. (2010). The cognitive underpinnings of effective teamwork: A meta-analysis. Journal of Applied Psychology, 95, 32-53. doi:10.1037/a0017328

Decuyper, S., Dochy, F., \& Van Den Bossche, P. (2010). Grasping the dynamic complexity of team learning: An integrative model for effective team learning in organisations. Educational Research Review, 5, 111-133. doi:10.1016/j.edurev.2010.02.002

Edmondson, A. (1999). Psychological safety and learning behavior in work teams. Administrative Science Quarterly, 44, 350-383. doi: $10.2307 / 2666999$

Edmondson, A. C. (2003). Managing the risk of learning: Psychological safety in work teams. In M. West (Ed.), International handbook of organizational teamwork (pp. 255276). London: Blackwell Publishing.

Edmondson, A. C., Dillon, J. R., \& Roloff, K. S. (2007). 6 Three perspectives on team learning. The Academy of Management Annals, 1, 269-314. doi:10.1080/078559811

Edmondson, A. C., Winslow, A. B., Bohmer, R. M., \& Pisano, G. P. (2003). Learning how and learning what: Effects of tacit and codified knowledge on performance improvement following technology adoption. Decision Sciences, 34, 197-224. doi:10.1111/ 1540-5915.02316

Edwards, B. D., Day, E. A., Arthur, W., \& Bell, S. T. (2006). Relationships among team ability composition, team mental models, and team performance. Journal of Applied Psychology, 91, 727-736. doi:10.1037/0021-9010.91.3.727

Ericksen, J., \& Dyer, L. (2004). Right from the start: Exploring the effects of early team events on subsequent project team development and performance. Administrative Science Quarterly, 49, 438471. doi:10.2307/4131442

Ericsson, K. A., Krampe, R. T., \& Tesch-Römer, C. (1993). The role of deliberate practice in the acquisition of expert performance. Psychological Review, 100, 363-406. doi:10.1037/0033295X.100.3.363

Fiol, C. M., \& Lyles, M. A. (1985). Organizational learning. Academy of Management Review, 10, 803-813. doi:10.5465/AMR.1985.4279103

Fussell, S. R., \& Krauss, R. M. (1989). The effects of intended audience on message production and comprehension: Reference in a common ground framework. Journal of Experimental Social Psychology, 25, 203-219. doi:10.1016/0022-1031(89)90019-X

Gersick, C. J. G. (1988). Time and transition in work teams: Toward a new model of group development. Academy of Management Journal, 31, 9-41. doi:10.2307/256496

Gevers, J. M. P., Rutte, C. G., \& Van Eerde, W. (2006). Meeting deadlines in work groups: Implicit and explicit mechanisms.
Applied Psychology: An International Review, 55, 52-72. doi:10.1111/j.1464-0597.2006.00228.x

Guchait, P., \& Hamilton, K. (2013). The temporal priority of team learning behaviors vs. shared mental models in service management teams. International Journal of Hospitality Management, 33, 1928. doi:10.1016/j.ijhm.2013.01.004

Hackman, J. R. (1987). The design of work teams. In J. W. Lorsch (Ed.), Handbook of organizational behaviour (pp. 315-342). New York, NY: Prentice Hall.

Hackman, J. R., \& Wageman, R. (2005). A theory of team coaching. Academy of Management Review, 30, 269-287. doi:10.5465/ AMR.2005.16387885

Humphrey, S. E., Morgeson, F. P., \& Mannor, M. J. (2009). Developing a theory of the strategic core of teams: A role composition model of team performance. Journal of Applied Psychology, 94, 48-61. doi:10.1037/a0012997

James, L. R., Demaree, R. J., \& Wolf, G. (1993). Rwg: An assessment of within group interrater agreement. Journal of Applied Psychology, 78, 306-309. doi:10.1037/0021-9010.78.2.306

Jehn, K. A. (1995). A multi method examination of the benefits and detriments of intragroup conflict. Administrative Science Quarterly, 40, 256-282.

Kanfer, R., \& Ackerman, P. L. (1989). Motivation and cognitive abilities: An integrative/ aptitude-treatment interaction approach to skill acquisition. Journal of Applied Psychology, 74, 657-690. doi:10.1037/0021-9010.74.4.657

Klimoski, R., \& Mohammed, S. (1994). Team mental model: Construct or metaphor? Journal of Management, 20, 403-437. doi:10.1177/ 0149206309356804

Kozlowski, S. W. J., \& Bell, B. S. (2008). Team learning, development, and adaptation. In V. I. Sessa \& M. London (Eds.), Work group learning: Understanding, improving and assessing how groups learn in organizations (pp. 15-44). New York, NY: Taylor \& Francis Group.

Kozlowski, S. W. J., \& Chao, G. T. (2012). Macrocognition, team learning, and team knowledge: Origins, emergence, and measurement. In E. Salas, S. M. Fiore, \& M. P. Letsky (Eds.), Theories of team cognition: Cross-disciplinary perspectives (pp. 19-48). New York, NY: Routledge.

Kozlowski, S. W. J., Chao, G. T., \& Jensen, J. M. (2010). Building an infrastructure for organizational learning: A multilevel approach. In S. W. J. Kozlowski \& E. Salas (Eds.), Learning training, and development in organizations (pp. 363-403). New York, NY: Routledge.

Kozlowski, S. W. J., Gully, S. M., Nason, E. R., \& Smith, E. M. (1999). Developing adaptive teams: A theory of compilation and performance across levels and time. In D. R. Ilgen \& E. D. Pulakos (Eds.), The changing nature of work performance: Implications for staffing, personnel actions, and development (pp. 240-292). San Francisco, CA: Jossey-Bass.

Kozlowski, S. W. J., \& Ilgen, D. R. (2006). Enhancing the effectiveness of work groups and teams. Psychological Science in the Public Interest, 7, 77-124. doi:10.1111/j.1529-1006.2006.00030.x

Kozlowski, S. W. J., \& Klein, K. J. (2000). A multi-level approach to theory and research in organizations: Contextual, temporal, and emergent processes. In K. J. Klein \& S. W. J. Kozlowski (Eds.), Multilevel theory, research, and methods in organizations (pp. 390). San Francisco, CA: Jossey-Bass.

Kraiger, K., Ford, J. K., \& Salas, E. (1993). Application of cognitive, skillbased, and affective theories of learning outcomes to new methods of training evaluation. Journal of Applied Psychology, 78, 311-328. doi:10.1037/0021-9010.78.2.311

Krauss, R. M., \& Fussell, S. R. (1991). Constructing shared communicative environments. In L. B. Resnick, J. M. Levine, \& S. D. Teasley (Eds.), Perspectives on socially-shared cognition. Washington, DC: American Psychological Association. 
Kulik, J. A., \& Kulik, C.-L. C. (1988). Timing of feedback and verbal learning. Review of Educational Research, 58, 79-97. doi:10.3102/ 00346543058001079

Lim, B.-C., \& Klein, K. J. (2006). Team mental models and team performance: A field study of the effects of team mental model similarity and accuracy. Journal of Organizational Behavior, 27, 403-418. doi:10.1002/job.387

MacMillan, J., Entin, E. E., \& Serfaty, D. (2004). Communication overhead: The hidden cost of team cognition. In E. Salas \& S. M. Fiore (Eds.), Team cognition: Understanding the factors that drive process and performance (pp. 61-82). Washington, DC: American Psychological Association.

March, J. G. (1991). Exploration and exploitation in organizational learning. Organization Science, 2, 71-87. doi:10.1287/orsc.2.1.71

Marks, M. A., Zaccaro, S. J., \& Mathieu, J. E. (2000). Performance implications of leader briefings and team-interaction training for team adaptation to novel environments. Journal of Applied Psychology, 85, 971-986. doi:10.1037/0021-9010.85.6.971

Marques-Quinteiro, P., Passos, A. M., \& Curral, L. (2014). Thought self-leadership and effectiveness in self-management teams. Leadership. Advance online publication. doi:10.1177/ 1742715014543579

Mathieu, J. E., Heffner, T. S., Goodwin, G. F., Salas, E., \& CannonBowers, J. A. (2000). The influence of shared mental models on team process and performance. Journal of Applied Psychology, 85, 273283. doi:10.1037/0021-9010.85.2.273

Mathieu, J. E., \& Rapp, T. L. (2009). Laying the foundation for successful team performance trajectories: The roles of team charters and performance strategies. Journal of Applied Psychology, 94, 90 103. doi: $10.1037 / \mathrm{a} 0013257$

Mathieu, J. E., \& Taylor, S. R. (2006). Clarifying conditions and decision points for mediational type inferences in organizational behavior. Journal of Organizational Behavior, 27, 1031-1056. doi:10.1002/job.406

Maynard, M. T., \& Gilson, L. L. (2014). The role of shared mental model development in understanding virtual team effectiveness. Group \& Organization Management, 39, 3-32. doi:10.1177/ 1059601113475361

Mohammed, S., Ferzandi, L., \& Hamilton, K. (2010). Metaphor no more: A 15-year review of the team mental model construct. Journal of Management, 36, 876-910. doi:10.1177/0149206309356804

Mohammed, S., \& Nadkarni, S. (2011). Temporal diversity and team performance: The moderating role of team temporal leadership. Academy of Management Journal, 54, 489-508. doi:10.5465/ AMJ.2011.61967991

Mohammed, S., \& Nadkarni, S. (2014). Are we all on the same temporal page? The moderating effects of temporal team cognition on the polychronicity diversity-team performance relationship. Journal of Applied Psychology, 99, 404-422. doi:10.1037/ a0035640

Moreland, R. L., \& McMinn, J. G. (2010). Group reflexivity and performance. In S. R. Thye \& E. J. Lawler (Eds.), Advances in Group Processes (Vol. 27, pp. 63-95). Emerald Group Publishing. Retrieved from http://www.emeraldinsight.com/doi/abs/10.1108/ S0882-6145\%282010\%290000027006

Pearsall, M. J., Ellis, A. P. J., \& Bell, B. S. (2010). Building the infrastructure: The effects of role identification behaviors on team cognition development and performance. Journal of Applied Psychology, 95, 192-200. doi:10.1037/a0017781

Pinheiro, J. C., \& Bates, D. M. (2000). Mixed-effects models in $S$ and $S$-PLUS. New York, NY: Springer.

Pisano, G. P., Bohmer, R. M., \& Edmondson, A. C. (2001). Organizational differences in rates of learning: Evidence from the adoption of minimally invasive cardiac surgery. Management Science, 47, 752-768. doi:10.1287/mnsc.47.6.752.9811
Pitariu, A. H., \& Ployhart, R. E. (2010). Explaining change: Theorizing and testing dynamic mediated longitudinal relationships. Journal of Management, 36, 405-429. doi:10.1177/ 0149206308331096

Ployhart, R. E., \& Vandenberg, R. J. (2010). Longitudinal research: The theory, design, and analysis of change. Journal of Management, 36 , 94-120. doi:10.1177/0149206309352110

Reagans, R., Argote, L., \& Brooks, D. (2005). Individual experience and experience working together: Predicting learning rates from knowing who knows what and knowing how to work together. Management Science, 51, 869-881. doi:10.1287/ mnsc. 1050.0366

Resick, C. J., Murase, T., Bedwell, W. L., Sanz, E., Jiménez, M., \& DeChurch, L. A. (2010). Mental model metrics and team adaptability: A multi-facet multi-method examination. Group Dynamics: Theory, Research, and Practice, 14, 332-349. doi:10.1037/ a0018822

Rico, R., Sánchez-Manzanares, M., Gil, F., \& Gibson, C. (2008). Team implicit coordination processes: A team knowledge-based approach. Academy of Management Review, 33, 163-184. doi:10.5465/AMR.2008.27751276

Roe, R. A. (2008). Time in applied psychology: The study of "what happens" rather than "what is". The European Psychologist, 13, 37-52. doi:10.1027/1016-9040.13.1.37

Roe, R. A., Gockel, C., \& Meyer, B. (2012). Time and change in teams: Where we are and where we are moving. European Journal of Work and Organizational Psychology, 21, 629-656. doi:10.1080/ 1359432X.2012.729821

Rosen, M. A., Bedwell, W. L., Wildman, J. L., Fritzsche, B. A., Salas, E., \& Burke, C. S. (2011). Managing adaptive performance in teams: Guiding principles and behavioral markers for measurement. Human Resource Management Review, 21, 107-122. doi:10.1016/j. hrmr.2010.09.003

Santos, C. M., \& Passos, A. M. (2013). Team mental models, relationship conflict and effectiveness over time. Team Performance Management, 19, 363-385. doi:10.1108/TPM-01-2013-0003

Savelsbergh, C., Gevers, J., Van Der Heijden, B. I. J. M., \& Poell, R. F. (2012). Team role stress: Relationships with team learning and performance in project teams. Group \& Organization Management, 37, 67-100. doi:10.1177/1059601111431977

Savelsbergh, C. M. J. H., Van Der Heijden, B. I. J. M., \& Poel, R. F. (2009). The development and empirical validation of a multidimensional measurement instrument for team learning behaviors. Small Group Research, 40, 578-607. doi:10.1177/1046496409340055

Schippers, M. C., Den Hartog, D. N., \& Koopman, P. L. (2007). Reflexivity in teams: A measure and correlates. Applied Psychology: An International Review, 56, 189-211. doi:10.1111/ j.1464-0597.2006.00250.x

Schippers, M. C., Den Hartog, D. N., Koopman, P. L., \& Van Knippenberg, D. (2008). The role of transformational leadership in enhancing team reflexivity. Human Relations, 61, 1593-1616. doi:10.1177/0018726708096639

Schippers, M. C., Den Hartog, D. N., Koopman, P. L., \& Wienk, J. A. (2003). Diversity and team outcomes: The moderating effects of outcome interdependence and group longevity and the mediating effect of reflexivity. Journal of Organizational Behavior, 24, 779802. doi: $10.1002 /$ job. 220

Schippers, M. C., Homan, A. C., \& Van Knippenberg, D. (2013). To reflect or not to reflect: Prior team performance as a boundary condition of the effects of reflexivity on learning and final team performance. Journal of Organizational Behavior, 34, 6-23. doi:10.1002/job.1784

Singer, J. D., \& Willet, J. B. (2003). Applied longitudinal data analysis: Modeling change and event occurrence. New York, NY: Oxford University Press. 
Sonnentag, S. (2012). Time in organizational research: Catching up on a long neglected topic in order to improve theory. Organizational Psychology Review, 2, 361-368. doi:10.1177/2041386612442079

Spector, P. E. (2006). Method variance in organizational research: Truth or urban legend? Organizational Research Methods, 9, 221-232. doi:10.1177/1094428105284955

Stachowski, A. A., Kaplan, S. A., \& Waller, M. J. (2009). The benefits of flexible team interaction during crises. Journal of Applied Psychology, 94, 1536-1543. doi:10.1037/a0016903

Standifer, R., \& Bluedorn, A. (2006). Alliance management teams and entrainment: Sharing temporal mental models. Human Relations, 59, 903-927. doi:10.1177/0018726706067596

Standifer, R. L., Raes, A. M. L., Peus, C., Passos, A. M., Santos, C. M., \& Weisweiler, S. (2015). Time in teams: Impact of cognitions and conflict. Journal of Managerial Psychology. Advance online publication. doi:10.1108/JMP-09-2012-0278

Stout, R. J., Cannon-Bowers, J. A., Salas, E., \& Milanovich, D. M. (1999). Planning, shared mental models, and coordinated performance: An empirical link is established. Human Factors: The Journal of the Human Factors and Ergonomics Society, 41, 61-71. doi:10.1518/ 001872099779577273

Tindale, R. S., Smith, C. M., Thomas, L. S., Filkins, J., \& Sheffey, S. (1996). Shared representations and asymmetric social influence processes in small groups. In E. Witte \& J. Davis (Eds.), Understanding group behavior: Consensual action by small groups (Vol. 1, pp. 81-103). Mahwah, NJ: Lawrence Erlbaum Associates.

Tindale, R. S., Stawiski, S., \& Jacobs, E. (2008). Shared cognitions and group learning. In V. Sessa \& M. London (Eds.), Work group learning: Understanding, improving, and assessing how groups learn in organizations (pp. 73-90). New York, NY: Lawrence Erlbaum Associates.

Uitdewilligen, S., Waller, M. J., \& Pitariu, A. H. (2013). Mental model updating and team adaptation. Small Group Research, 44, 127-158. doi:10.1177/1046496413478205
Van Der Vegt, G., \& Bunderson, S. (2005). Learning and performance in multidisciplinary teams: The importance of collective team identification. Academy of Management Journal, 48, 532-547. doi:10.5465/AMJ.2005.17407918

Van Dyck, C., Frese, M., Baer, M., \& Sonnentag, S. (2005). Organizational error management culture and its impact on performance: A two-study replication. Journal of Applied Psychology, 90, 1228-1240. doi:10.1037/0021-9010.90.6.1228

Van Ginkel, W. P., Tindale, R. S., \& Van Knippenberg, D. (2009). Team reflexivity, development of shared task representations, and the use of distributed information in group decision making. Group Dynamics: Theory, Research, and Practice, 13, 265-280. doi:10.1037/a0016045

Van Woerkom, M., \& Croon, M. (2009). The relationships between team learning activities and team performance. Personnel Review, 38, 560-577. doi:10.1108/00483480910978054

Vashdi, D. R., Bamberger, P. A., \& Erez, M. (2013). Can surgical teams ever learn? The role of coordination, complexity, and transitivity in action team learning. Academy of Management Journal, 56, 945971. doi:10.5465/amj.2010.0501

Webber, S. S., Chen, G., Payne, S. C., Marsh, S. M., \& Zaccaro, S. J. (2000). Enhancing team mental model measurement with performance appraisal practices. Organizational Research Methods, 3, 307-322. doi:10.1177/109442810034001

West, M. A. (2000). Reflexivity, revolution and innovation in work teams. In M. M. Beyerlein, D. A. Johnson, \& S. T. Beyerlein (Eds.), Product development teams (Vol. 5, pp. 1-29). Stamford, CT: JAI Press.

Wilson, J. M., Goodman, P. S., \& Cronin, M. A. (2007). Group learning. Academy of Management Review, 32, 1041-1059. doi:10.5465/AMR.2007.26585724

Wong, S. S. (2004). Distal and local group learning: Performance tradeoffs and tensions. Organization Science, 15, 645-656. doi:10.1287/ orsc. 1040.0080

\section{Shared mental model scale Task dimension}

(1) Clear understanding of team objectives; Team members understanding regarding the strategy to make decisions

(2) Clear understanding of team objectives; Clear understanding about management reports and their implications to make decisions

(3) Clear understanding of team objectives; Identical interpretation of information about the Company and the Market

(4) Team members understanding regarding the strategy to make decisions; Clear understanding about management reports and their implications to make decisions

(5) Team members understanding regarding the strategy to make decisions; Identical interpretation of information about the company and the market
APPENDIX

(6) Clear understanding about management reports and their implications to make decisions; Identical interpretation of information about the company and the market

\section{Team dimension}

(1) Communicate openly with each other; Trust in each other

(2) Communicate openly with each other; Mutual support to perform tasks

(3) Communicate openly with each other; Work well together

(4) Trust in each other; Mutual support to perform tasks

(5) Trust in each other; Work well together 
(6) Mutual support to perform tasks; Work well together

\section{Temporal dimension}

(1) Allocate the time available for each activity; Agreement about time needed to make decisions

(2) Allocate the time available for each activity; Planning the work that each team member needs to perform
(3) Allocate the time available for each activity; Establishment of a plan for weekly activities

(4) Agreement about time needed to make decisions; Planning the work that each team member needs to perform

(5) Agreement about time needed to make decisions; Establishment of a plan for weekly activities

(6) Planning the work that each team member needs to perform; Establishment of a plan for weekly activities 